\title{
Pengaruh Dosis dan Frekuensi Aplikasi Pupuk Organik Cair (POC) Terhadap Pertumbuhan dan Hasil Padi (Oryza sativa, L.)
}

Agatha Niis ${ }^{a}$ dan Nikolas Nik ${ }^{b}$

${ }^{a}$ Fakultas Pertanian, Universitas Timor, Kefamenanu, TTU - NTT, Indonesia.

${ }^{b}$ Fakultas Pertanian, Universitas Timor, Kefamenanu, TTU - NTT, Indonesia.

\section{Article Info}

Article history:

Received 21 Oktober 2016

Received in revised form 27 November 2016

Accepted 6 Januari 2017

Keywords:

Dosis POC

Frekuensi Aplikasi POC

Oryza sativa, L

\begin{abstract}
Abstrak
Tujuan Penelitian ini adalah untuk Mengetahui pengaruh pupuk organik cair terhadap pertumbuhan dan hasil padi sawah serta Mengetahui dosis dan frekuensi optimum yang berpengaruh terhadap pertumbuhan dan hasil tanaman padi sawah. Penelitian ini dilaksanakan pada bulan Maret sampai Juni 2016 di daerah persawahan Motamaro Desa Tasain, Kecamatan Raimanuk, Kabupaten Belu, Provinsi Nusa Tenggara Timur dengan menggunakan Rancangan Acak Kelompok (RAK) faktorial 3 x 3 yang diulang 3 kali. Faktor pertama adalah dosis POC (D) terdiri dari tiga aras yaitu dosis $2 \mathrm{~L} /$ ha $\left(\mathrm{D}_{1}\right), 4 \mathrm{~L} / \mathrm{ha}\left(\mathrm{D}_{2}\right), 6 \mathrm{~L} / \mathrm{ha}\left(\mathrm{D}_{3}\right)$. Faktor kedua adalah frekuensi pemberian $(\mathrm{F})$ terdiri dari tiga aras yaitu 2 kali $\left(\mathrm{F}_{1}\right), 4$ kali $\left(\mathrm{F}_{2}\right), 6$ kali $\left(\mathrm{F}_{3}\right)$. Hasil penelitian menunjukkan bahwa dosis pupuk organik cair terbaik adalah 6 liter dengan hasil berat kering biji sebesar $8,90 \mathrm{t} / \mathrm{ha}$, sedangkan frekuensi penyemprotan pupuk organik cair tidak berbeda nyata. (O2017 dipublikasikan oleh Savana Cendana.
\end{abstract}

\section{Pendahuluan}

Padi (Oryza sativa L.) merupakan salah satu tanaman budidaya yang sudah dikenal sebagai tanaman pangan dan pada saat ini produksinya menempati urutan ketiga dari semua serealia setelah jagung dan gandum (Purnamaningsih, 2006) Kandungan nilai gizi cukup tinggi karbohidrat 360 kalori, protein $6,8 \mathrm{~g}$, minera $6 \mathrm{mg}$ dan 0,8 mg (Astawan, 2004). Pada umumnya masyarakat kabupaten Belu mengkonsumsi beras (nasi) sebagai makanan pokok oleh karenanya permintaan akan beras dari waktu ke waktu semakin tinggi.

Kabuapten Belu memiliki potensi yang sangat besar untuk pengembangan padi sawah. Pada tahun 2014 luas areal penanaman komoditas padi sawah adalah seluas 7.180 ha dengan luas panen 5.259 ha dan produksi sebesar 20.059 ton gabah kering panen atau 13.676 ton beras. Jumlah ini belum dapat memenuhi kebutuhan beras bagi sekitar 382.375 jiwa penduduk di Kabupaten Belu, sehingga masih harus mendatangkan dari daerah lain guna mencukupi kebutuhan masyarakat. Melihat keadaan ini tentunya sangat dibutuhkan adanya upaya untuk meningkatkan produksi padi yang dapat digalakan melalui swasembada beras (BPS Kab. Belu, 2014).

Meningkatnya permintaan akan beras sehingga mendorong perlunya melakukan teknik budidaya yaitu salah satunya adalah pemberian pupuk organik cair (POC) dengan memperhatikan frekuensi pemberiannya. Hasil pengamatan di tingkat petani dalam budidaya tanaman padi sawah umumnya masih menggunakan pupuk kimia, namun sebagian petani ada yang sudah menggunakan pupuk organik cair (POC), Yang mana memiliki mamfaat bag tanaman yaitu Untuk menyuburkan tanaman, menjaga stabilitas unsur hara dalam tanah, mengurangi dampak sampah organik di lingkungan sekitar, membantu revitalisasi produktivitas tanah, meningkatkan kualitas produk (Suriadikarta, 2006). POC yang digunakan oleh petani kabupaten Belu belum memperhatikan dosis dan frekuensi aplikasinya.Kebiasaan petani di Kabupaten Belu dalam mengaplikasikan POC dosis dan frekuensinya tidak menentu.

Hasil wawancara petani padi sawah di Desa Tasain Kecamatan Raimanuk menyatakan bahwa penyemprotan terhadap tanaman padi sawah selama masa pertumbuhan sampai panen dapat dilakukan sebanyak 4 kali, dengan dosis 7 tutup botol (100 mL) / $15 \mathrm{~L}$ air. Selanjutnya Wawo (2013) melaporkan bahwa pemberian pupuk bokashi cair dengan dosis $12 \mathrm{~L} /$ ha dapat meningkatkan hasil panen padi sawah sebesar 7,9 ton/ha. Penelitian ini bertujuan untuk mengetahui pengaruh pupuk organik cair terhadap pertumbuhan dan hasil padi sawah, dan mengetahui dosis dan frekuensi optimum yang berpengaruh terhadap pertumbuhan dan hasil tanaman padi sawah.

\section{Metode}

Penelitian ini dilaksanakan pada bulan Maret sampai Juni 2016 di daerah persawahan Motamaro Desa Tasain, Kecamatan Raimanuk, Kabupaten Belu, Provinsi Nusa Tenggara Timur. Penelitian ini menggunakanRancangan Acak Kelompok (RAK) faktorial 3 x 3 yang diulang 3 kali. Faktor pertama adalah dosis POC (D) terdiri dari tiga aras yaitu dosis $21 /$ ha $\left(D_{1}\right), 4$ 1/ha $\left(D_{2}\right), 61 / h^{2}\left(D_{3}\right)$ Faktor kedua adalah frekuensi pemberian $(\mathrm{F})$ terdiri dari tiga aras yaitu 2 kali $\left(\mathrm{F}_{1}\right), 4$ kali $\left(\mathrm{F}_{2}\right), 6$ kali $\left(\mathrm{F}_{3}\right)$. POC yang digunakan adalah merek TOP. Pemberian POC dilakukan dengan penyemprotan dan menggunakan hands prayer yang bervolume 1 liter. Penyemprotan ini disesuaikan dengan perlakuan yakni $2 \mathrm{~L} / \mathrm{ha}$ (D1) setara dengan $0,5 \mathrm{~mL} /$ petak,4 L/ha (D2) setara dengan $0,96 \mathrm{~mL} /$ petak dan $6 \mathrm{~L} / \mathrm{ha}$ (D3) setara 1,44 mL/petak. Sedangkan frekuensi aplikasi dilakukan 2 kali pada 1530 HST, (F1) 4 kali pada 1530 45, dan 60 HST, (F2) 6 kali pada 1530 456075 dan 85 HST (F3).

Data hasil pengamatan kemudian dianalisis dengan menggunakan sidik ragam (Anova) Rancangan Acak Kelompok (RAK). Rata-rata perlakuan selanjutnya diuji lanjut dengan menggunakan Duncan Multiple Range Test (DMRT) dengan tingkat signifikasi 5\% sesuai petunjuk Gomez dan Gomez (1995). Analisis data menggunakan program SAS 9.1.

\section{Hasil dan Pembahasan}

\subsection{Suhu Tanah}

Tidak terjadi interaksi antara perlakuan dosis pupuk organik cair dengan frekuensi pemberian pupuk organik cair pada pengamatan suhu tanah. Tidak terdapat beda nyata antar faktor tunggal baik faktor tunggal dosis pupuk organik cair maupun faktor tunggal frekuensi pemberian pupuk organik cair. Suhu tanah terus mengalami penurunan pada setiap waktu pengamatan. Penurunan suhu tanah diakibatkan oleh penutupan permukaan lahan oleh tajuk tanaman yang terus berkembang dari waktu ke waktu.

Tabel 1. Suhu Tanah

\begin{tabular}{cccccc} 
Waktu & Dosis POC & \multicolumn{3}{c}{ Frekuensi Pemberian } & \multirow{2}{*}{ Rerata } \\
\cline { 2 - 5 } Pengamatan & $(\mathrm{L} / \mathrm{ha})$ & 2 & 4 & 6 & \\
\hline \multirow{4}{*}{$30 \mathrm{HST}$} & 2 & 28,51 & 28,58 & 28,38 & $28,5 \mathrm{a}$ \\
& 4 & 29,00 & 28,83 & 28,00 & $28,6 \mathrm{a}$ \\
& 6 & 29,09 & 28,63 & 28,74 & $28,8 \mathrm{a}$ \\
\cline { 2 - 5 } & Rerata & $28,87 \mathrm{a}$ & $28,68 \mathrm{a}$ & $28,37 \mathrm{a}$ & $(-)$ \\
\hline \multirow{4}{*}{45 HST } & 2 & 27,79 & 28,40 & 27,16 & $27,78 \mathrm{a}$ \\
& 4 & 27,71 & 27,62 & 27,98 & $27,77 \mathrm{a}$ \\
& 6 & 28,01 & 27,49 & 27,86 & $27,78 \mathrm{a}$ \\
\cline { 2 - 5 } & Rerata & $27,84 \mathrm{a}$ & $27,84 \mathrm{a}$ & $27,66 \mathrm{a}$ & $(-)$ \\
\hline \multirow{5}{*}{$60 \mathrm{HST}$} & 2 & 26,47 & 26,89 & 26,41 & $26,59 \mathrm{a}$ \\
& 4 & 26,40 & 26,27 & 26,59 & $26,42 \mathrm{a}$ \\
& 6 & 26,08 & 26,63 & 25,83 & $26,18 \mathrm{a}$ \\
\cline { 2 - 5 } & Rerata & $26,31 \mathrm{a}$ & $26,60 \mathrm{a}$ & $26,28 \mathrm{a}$ & $(-)$ \\
\hline
\end{tabular}

Keterangan : Angka pada baris dan kolom diikuti dengan huruf sama tidak berbeda pada taraf nyata $(\alpha) 5 \%$ menurut uji DMRT. (-): Tidak terjadi interaksi antar faktor.

\subsection{Jumlah Anakan}

Hasil sidik ragam (Anova) menunjukkan tidak terjadi interaksi antara perlakuan dosis pupuk organik cair dengan frekuensi pemberian pupuk organik cair terhadap jumlah anakan pada setiap pengamatan. Pengaruh utama dosis pupuk organik cair $6 \mathrm{~L} / \mathrm{ha}$ menghasilkan tanaman dengan jumlah anakan paling banyak pada pengamatan 30 dan $45 \mathrm{HST}$, tetapi tidak berbeda nyata dengan dosis pupuk organik cair $2 \mathrm{~L} /$ ha dan $4 \mathrm{~L} / \mathrm{ha}$, pada pengamatan $60 \mathrm{HST} 2 \mathrm{~L} / \mathrm{ha}$ menghasilkan anakan paling banyak $(26,59)$ tetapi tidak berbeda nyata dengan 2 L/ha dan $4 \mathrm{~L} / \mathrm{ha}$. Pengaruh utama frekuensi pemberian pupuk cair 2 kali menghasilkan anakan paling banyak pada pengamatan 30 dan 45 HST tetapi tidak berbeda nyata dengan pemberian 4 dan 6 kali, sedangkan pada pengamatan 60 HST frekuensi pemberian 4 kali menghasilkan tanaman dengan jumlah anakan paling banyak tetapi tidak berbeda nyata dengan 2 dan 6 kali.

Tabe 2. Jumlah Anakan

\begin{tabular}{cccccc}
\hline Waktu & Dosis POC & \multicolumn{3}{c}{ Frekuensi Pemberian } & \multirow{2}{*}{ Rerata } \\
\cline { 2 - 5 } Pengamatan & $(\mathrm{L} / \mathrm{ha})$ & 2 & 4 & 6 & \\
\hline \multirow{3}{*}{$30 \mathrm{HST}$} & 2 & 15,27 & 14,33 & 15,93 & $15,18 \mathrm{a}$ \\
& 4 & 15,13 & 13,60 & 13,53 & $14,09 \mathrm{a}$ \\
& 6 & 12,93 & 15,33 & 13,27 & $13,84 \mathrm{a}$ \\
\cline { 2 - 5 } & Rerata & $14,44 \mathrm{a}$ & $14,42 \mathrm{a}$ & $14,24 \mathrm{a}$ & $(-)$ \\
\hline \multirow{4}{*}{$45 \mathrm{HST}$} & 2 & 16,60 & 17,80 & 18,47 & $17,62 \mathrm{a}$ \\
& 4 & 18,33 & 17,33 & 17,60 & $17,76 \mathrm{a}$ \\
& 6 & 17,47 & 18,60 & 18,00 & $18,02 \mathrm{a}$ \\
\cline { 2 - 5 } & Rerata & $17,47 \mathrm{a}$ & $17,91 \mathrm{a}$ & $18,02 \mathrm{a}$ & $(-)$ \\
\hline \multirow{5}{*}{$60 \mathrm{HST}$} & 2 & 17,40 & 18,47 & 18,87 & $18,24 \mathrm{a}$ \\
& 4 & 19,33 & 18,00 & 17,93 & $18,42 \mathrm{a}$ \\
& 6 & 17,60 & 19,00 & 18,40 & $18,33 \mathrm{a}$ \\
\cline { 2 - 5 } & Rerata & $18,11 \mathrm{a}$ & $18,49 \mathrm{a}$ & $18,40 \mathrm{a}$ & $(-)$ \\
\hline
\end{tabular}

Keterangan : Angka pada baris dan kolom diikuti dengan huruf sama tidak berbeda pada taraf nyata $(\alpha) 5 \%$ menurut uji DMRT. (-) : Tidak terjadi interaksi antar faktor. 


\subsection{Jumlah Anakan Produktif}

Hasil sidik ragam (Anova) menunjukkan tidak terjadi interaksi antara perlakuan dosis pupuk organik cair dengan frekuensi pemberian pupuk organik cair pada pengamatan jumlah anakan produktif. Pengaruh utama dosis pupuk organik cair $6 \mathrm{~L} / \mathrm{ha}$ menghasilkan tanaman dengan jumlah anakan produktif paling banyak $(12,07)$ tetapi tidak berbeda nyata dibanding tanaman dengan dosis pupuk organik cair $2 \mathrm{~L} / \mathrm{ha}$ dan $4 \mathrm{~L} / \mathrm{ha}$, sedangkan pengaruh utama frekuensi pemberian pupuk cair 2 kali menghasilkan anakan produktif paling banyak 11,51 anakan tetapi tidak berbeda nyata dengan pemberian 4 dan 6 kali.

Tabel 3. Jumlah Anakan Produktif

\begin{tabular}{ccccc}
\hline \multirow{2}{*}{$\begin{array}{c}\text { Dosis POC } \\
\text { (L/ha) }\end{array}$} & \multicolumn{3}{c}{ Frekuensi Pemberian } & \multirow{2}{*}{ Rerata } \\
\cline { 2 - 4 } & 2 & 4 & 6 & \\
\hline 4 & 11,13 & 9,53 & 11,93 & $10,87 \mathrm{a}$ \\
6 & 11,73 & 10,87 & 10,53 & $11,04 \mathrm{a}$ \\
& 11,67 & 12,60 & 11,93 & $12,07 \mathrm{a}$ \\
\hline Rerata & $11,51 \mathrm{a}$ & $11,00 \mathrm{a}$ & $11,47 \mathrm{a}$ & $(-)$ \\
\hline
\end{tabular}

Keterangan : Angka pada baris dan kolom diikuti dengan huruf sama tidak berbeda pada taraf nyata $(\alpha) 5 \%$ menurut uji DMRT. (-) : Tidak terjadi interaksi antar faktor.

\subsection{Jumlah Anakan Non Produktif}

Hasil sidik ragam (Anova) menunjukkan tidak terjadi interaksi antara perlakuan dosis pupuk organik cair dengan frekuensi pemberian pupuk organik cair pada pengamatan jumlah anakan non produktif. Pengaruh utama dosis pupuk organik cair $2 \mathrm{~L} / \mathrm{ha}$ menghasilkan tanaman dengan jumlah anakan non produktif paling banyak $(7,38)$ tetapi tidak berbeda nyata dibanding tanaman dengan dosis pupuk organik cair $2 \mathrm{~L} /$ ha dan $4 \mathrm{~L} / \mathrm{ha}$, sedangkan pengaruh utama frekuensi pemberian pupuk cair 4 kali menghasilkan anakan non produktif paling banyak $(7,49)$ anakan tetapi tidak berbeda nyata dengan pemberian 2 dan 6 kali.

Tabel 4. Jumlah Anakan Non Produktif

\begin{tabular}{ccccc}
\hline \multirow{2}{*}{ Dosis POC (L/ha) } & \multicolumn{3}{c}{ Frekuensi Pemberian } & \multirow{2}{*}{ Rerata } \\
\cline { 2 - 4 } & 2 & 4 & 6 & \\
\hline 2 & 6,27 & 8,93 & 6,93 & $7,38 \mathrm{a}$ \\
4 & 7,60 & 7,13 & 7,40 & $7,38 \mathrm{a}$ \\
6 & 5,93 & 6,40 & 6,47 & $6,27 \mathrm{a}$ \\
\hline Rerata & $6,60 \mathrm{a}$ & $7,49 \mathrm{a}$ & $6,93 \mathrm{a}$ & $(-)$ \\
\hline
\end{tabular}

Keterangan : Angka pada baris dan kolom diikuti dengan huruf sama tidak berbeda pada taraf nyata $(\alpha) 5 \%$ menurut uji DMRT. (-) : Tidak terjadi interaksi antar faktor.

\subsection{Jumlah Biji Per Malai}

Hasil sidik ragam (Anova) menunjukkan tidak terjadi interaksi antara perlakuan dosis pupuk organik cair dengan frekuensi pemberian pupuk organik cair pada pengamatan jumlah anakan produktif. Pengaruh utama dosis pupuk organik cair $6 \mathrm{~L} /$ ha menghasilkan tanaman dengan jumlah biji per malai paling banyak $(107,38)$ berbeda nyata dibanding tanaman dengan dosis pupuk organik cair $2 \mathrm{~L} /$ ha dan $4 \mathrm{~L} / \mathrm{ha}$, sedangkan pengaruh utama frekuensi pemberian pupuk cair 6 kali menghasilkan jumlah biji per malai paling banyak $(104,96)$ tetapi tidak berbeda nyata dengan pemberian 2 dan 4 kali.

Tabel 5. Jumlah Biji Per Malai

\begin{tabular}{ccccc}
\hline Dosis POC & \multicolumn{3}{c}{ Frekuensi Pemberian } & \multirow{2}{*}{ Rerata } \\
\cline { 2 - 4 }$(\mathrm{L} / \mathrm{ha})$ & 2 & 4 & 6 & \\
\hline 2 & $96,21 \mathrm{cb}$ & $100,55 \mathrm{cb}$ & $96,55 \mathrm{cb}$ & $97,77 \mathrm{~b}$ \\
4 & $100,80 \mathrm{cb}$ & $101,13 \mathrm{cb}$ & $95,40 \mathrm{c}$ & $99,11 \mathrm{~b}$ \\
6 & $90,58 \mathrm{c}$ & $108,63 \mathrm{~b}$ & $122,93 \mathrm{a}$ & $107,38 \mathrm{a}$ \\
\hline Rerata & $95,86 \mathrm{~b}$ & $103,44 \mathrm{a}$ & $104,96 \mathrm{a}$ & $(+)$ \\
\hline
\end{tabular}

Keterangan : Angka pada baris dan kolom diikuti dengan huruf sama tidak berbeda pada taraf nyata $(\alpha) 5 \%$ menurut uji DMRT. (+) : Terjadi interaksi antar faktor.

\subsection{Jumlah Biji Hampa Per Malai}

Hasil sidik ragam (Anova) menunjukkan tidak terjadi interaksi antara perlakuan dosis pupuk organik cair dengan frekuensi pemberian pupuk organik cair pada pengamatan jumlah biji hampa per malai. Pengaruh utama dosis pupuk organik cair $2 \mathrm{~L}$ /ha menghasilkan tanaman dengan jumlah biji hampa paling banyak $(16,08)$ tetapi tidak berbeda nyata dibanding tanaman dengan dosis pupuk organik cair $4 \mathrm{~L} /$ ha dan $6 \mathrm{~L} / \mathrm{ha}$, sedangkan pengaruh utama frekuensi pemberian pupuk cair 2 kali menghasilkan jumlah biji hampa paling banyak $(15,98)$ anakan tetapi tidak berbeda nyata dengan pemberian 4 dan 6 kali.

Tabel 6. Jumlah Biji Hampa Per Malai

\begin{tabular}{ccccc}
\hline \multirow{2}{*}{$\begin{array}{c}\text { Dosis POC } \\
(\mathrm{L} / \mathrm{ha})\end{array}$} & \multicolumn{3}{c}{ Frekuensi Pemberian } & \multirow{2}{*}{ Rerata } \\
\cline { 2 - 4 } 2 & 16,50 & 4 & 6 & \\
\hline 4 & 16,90 & 15,90 & 15,83 & $16,08 \mathrm{a}$ \\
6 & 14,54 & 13,64 & 14,90 & $15,88 \mathrm{a}$ \\
\hline Rerata & $15,98 \mathrm{a}$ & $15,13 \mathrm{a}$ & $14,22 \mathrm{a}$ & $(-)$ \\
\hline
\end{tabular}

Keterangan : Angka pada baris dan kolom diikuti dengan huruf sama tidak berbeda pada taraf nyata $(\alpha) 5 \%$ menurut uji DMRT. (-) : Tidak terjadi interaksi antar faktor.

\subsection{Jumlah Biji Bernas Per Malai}

Hasil sidik ragam (Anova) menunjukkan terjadi interaksi antara perlakuan dosis pupuk organik cair dengan frekuensi pemberian pupuk organik cair pada pengamatan jumlah biji bernas per malai. Pengaruh utama dosis pupuk organik cair $6 \mathrm{~L} /$ ha menghasilkan tanaman dengan jumlah biji per malai paling banyak $(8,90 \mathrm{t} / \mathrm{ha})$ berbeda nyata dibanding tanaman dengan dosis pupuk organik cair 2 $\mathrm{L} / \mathrm{ha}$ dan $4 \mathrm{~L} / \mathrm{ha}$, sedangkan pengaruh utama frekuensi pemberian pupuk cair 6 kali juga menghasilkan jumlah biji bernas per malai paling banyak $(90,73)$ dan berbeda nyata dengan pemberian 2 dan 4 kali.

Tabel 7. Jumlah Biji Bernas Per Malai

\begin{tabular}{ccccc}
\hline Dosis POC & \multicolumn{3}{c}{ Frekuensi Pemberian } & \multirow{2}{*}{ Rerata } \\
\cline { 2 - 4 }$(\mathrm{L} / \mathrm{ha})$ & 2 & 4 & 6 & \\
\hline 2 & $79,71 \mathrm{c}$ & $84,65 \mathrm{cb}$ & $80,72 \mathrm{c}$ & $81,69 \mathrm{~b}$ \\
4 & $83,89 \mathrm{cb}$ & $85,29 \mathrm{cb}$ & $80,50 \mathrm{c}$ & $83,23 \mathrm{~b}$ \\
6 & $76,04 \mathrm{c}$ & $94,78 \mathrm{~b}$ & $110,98 \mathrm{a}$ & $93,93 \mathrm{a}$ \\
\hline Rerata & $79,88 \mathrm{~b}$ & $88,24 \mathrm{a}$ & $90,73 \mathrm{a}$ & $(+)$ \\
\hline Keterangan : Angka pada baris dan kolom diikuti dengan huruf sama tidak berbeda pada
\end{tabular}

\subsection{Jumlah Biji Bernas Per Rumpun}

Hasil sidik ragam (Anova) menunjukkan tidak terjadi interaksi antara perlakuan dosis pupuk organik cair dengan frekuensi pemberian pupuk organik cair pada pengamatan jumlah biji bernas per rumpun. Pengaruh utama dosis pupuk organik cair $6 \mathrm{~L} / \mathrm{ha}$ menghasilkan tanaman dengan jumlah biji bernas paling banyak $(1085,24)$ berbeda nyata dibanding tanaman dengan dosis pupuk organik cair $2 \mathrm{~L} / \mathrm{ha}$ dan $4 \mathrm{~L} / \mathrm{ha}$, sedangkan pengaruh utama frekuensi pemberian pupuk cair tidak berbeda nyata.

Tabel 8. Jumlah Biji Bernas Per Rumpun

\begin{tabular}{ccccc}
\hline Dosis POC & \multicolumn{3}{c}{ Frekuensi Pemberian } & \multirow{2}{*}{ Rerata } \\
\cline { 2 - 4 }$(\mathrm{L} / \mathrm{ha})$ & 2 & 4 & 6 & \\
\hline 2 & 857,07 & 809,20 & 963,33 & $876,53 \mathrm{~b}$ \\
4 & 961,73 & 923,60 & 848,00 & $911,11 \mathrm{~b}$ \\
6 & 888,00 & 1080,93 & 1286,80 & $1085,24 \mathrm{a}$ \\
\hline Rerata & $902,27 \mathrm{a}$ & $937,91 \mathrm{a}$ & $1032,71 \mathrm{a}$ & $(-)$
\end{tabular}

Keterangan : Angka pada baris dan kolom diikuti dengan huruf sama tidak berbeda pada taraf nyata $(\alpha) 5 \%$ menurut uji DMRT. (-) : Tidak terjadi interaksi antar faktor.

\subsection{Presentase Jumlah Biji Bernas}

Hasil sidik ragam (Anova) menunjukkan tidak terjadi interaksi antara perlakuan dosis pupuk organik cair dengan frekuensi pemberian pupuk organik cair pada pengamatan presentase jumlah biji bernas. Perlakuan dosis pupuk cair dan frekuensi pemberian nyata mempengaruhi presentase jumlah biji bernas. Pengaruh utama dosis pupuk organik cair $6 \mathrm{~L} / \mathrm{ha}$ menghasilkan tanaman dengan presentase jumlah biji bernas paling tinggi $(87,2 \%)$, sedangkan pengaruh utama frekuensi pemberian pupuk cair juga menghasilkan tanaman dengan presentase jumlah biji bernas tertinggi yaitu $86,2 \%$.

Tabel 9. Presentase Jumlah Biji Bernas

\begin{tabular}{ccccc}
\hline \multirow{2}{*}{ Dosis POC $(\mathrm{L})$} & \multicolumn{3}{c}{ Frekuensi Pemberian } & \multirow{2}{*}{ Rerata } \\
\cline { 2 - 4 } & 2 & 4 & 6 & \\
\hline 2 & 82,8 & 84,4 & 83,8 & $83,7 \mathrm{~b}$ \\
4 & 83,4 & 84,9 & 84,6 & $84,3 \mathrm{~b}$ \\
6 & 83,9 & 87,4 & 90,2 & $87,2 \mathrm{a}$ \\
\hline Rerata & $83,3 \mathrm{~b}$ & $85,6 \mathrm{ab}$ & $86,2 \mathrm{a}$ & $(-)$ \\
\hline
\end{tabular}

Keterangan : Angka pada baris dan kolom diikuti dengan huruf sama tidak berbeda pada taraf nyata $(\alpha) 5 \%$ menurut uji DMRT. $(-)$ : Tidak terjadi interaksi antar faktor.

\subsection{Bobot Kering Biji Hampa Per Tanaman Sampel}

Hasil sidik ragam (Anova) menunjukkan terjadi interaksi antara perlakuan dosis pupuk organik cair dengan frekuensi pemberian pupuk organik cair pada pengamatan bobot kering biji hampa per tanaman sampel. Pengaruh utama dosis pupuk organik cair $6 \mathrm{~L} / \mathrm{ha}$ menghasilkan tanaman dengan bobot kering biji hampa per tanaman sampel paling berat $(1,60 \mathrm{~g})$ tidak berbeda nyata dibanding tanaman dengan dosis pupuk organik cair $2 \mathrm{~L} /$ ha dan $4 \mathrm{~L} /$ ha, sedangkan pengaruh utama frekuensi pemberian pupuk cair tidak berbeda nyata.

\section{Tabel 10. Berat Kering Biji Hampa Per Tanaman Sampel (G)}

\begin{tabular}{ccccc}
\hline \multirow{2}{*}{ Dosis POC $(\mathrm{L} / \mathrm{ha})$} & \multicolumn{3}{c}{ Frekuensi Pemberian } & \multirow{2}{*}{ Rerata } \\
\cline { 2 - 4 } & 2 & 4 & 6 & \\
\hline 2 & $1,43 \mathrm{~b}$ & $1,07 \mathrm{~b}$ & $1,45 \mathrm{~b}$ & $1,32 \mathrm{a}$ \\
4 & $1,61 \mathrm{ab}$ & $1,47 \mathrm{ab}$ & $1,21 \mathrm{~b}$ & $1,43 \mathrm{a}$ \\
6 & $1,64 \mathrm{ab}$ & $2,03 \mathrm{a}$ & $1,13 \mathrm{~b}$ & $1,60 \mathrm{a}$ \\
\hline Rerata & $1,56 \mathrm{a}$ & $1,52 \mathrm{a}$ & $1,27 \mathrm{a}$ & $(+)$ \\
\hline Keterangan : Angka pada baris dan kolom diikuti dengan huruf & sama tidak berbeda pada
\end{tabular}
taraf nyata $(\alpha) 5 \%$ menurut uji DMRT. (+) : Terjadi interaksi antar faktor.

\subsection{Bobot Kering Biji Per Tanaman}

Hasil sidik ragam (Anova) menunjukkan tidak terjadi interaksi antara perlakuan dosis pupuk organik cair dengan frekuensi pemberian pupuk organik cair pada pengamatan bobot kering biji per tanaman. Pengaruh utama dosis pupuk organik cair $6 \mathrm{~L} / \mathrm{ha}$ menghasilkan tanaman dengan bobot kering berangkasan paling berat $(29,65 \mathrm{~g})$ berbeda nyata dibanding tanaman dengan dosis pupuk organik cair $2 \mathrm{~L} / \mathrm{ha}$ dan $4 \mathrm{~L} / \mathrm{ha}$, sedangkan pengaruh utama frekuensi pemberian pupuk cair tidak berbeda nyata. 
Tabel 11. Bobot Kering Biji (g)

\begin{tabular}{ccccc}
\hline \multirow{2}{*}{ Dosis POC (L/ha) } & \multicolumn{3}{c}{ Frekuensi Pemberian } & \multirow{2}{*}{ Rerata } \\
\cline { 2 - 4 } & 2 & 4 & 6 & \\
\hline 2 & 24,11 & 18,69 & 23,93 & $22,24 \mathrm{~b}$ \\
4 & 24,69 & 27,70 & 24,61 & $25,66 \mathrm{ab}$ \\
6 & 25,35 & 31,18 & 32,43 & $29,65 \mathrm{a}$ \\
\hline Rerata & $24,72 \mathrm{a}$ & $25,86 \mathrm{a}$ & $26,99 \mathrm{a}$ & $(-)$ \\
\hline
\end{tabular}

Keterangan : Angka pada baris dan kolom diikuti dengan huruf sama tidak berbeda pada taraf nyata $(\alpha) 5 \%$ menurut uji DMRT. $(-)$ : Tidak terjadi interaksi antar faktor.

\subsection{Bobot 1000 Biji}

Hasil sidik ragam (Anova) menunjukkan tidak terjadi interaksi antara perlakuan dosis pupuk organik cair dengan frekuensi pemberian pupuk organik cair pada pengamatan bobot 1000 biji. Pengaruh utama dosis pupuk organik cair $6 \mathrm{~L} /$ ha menghasilkan tanaman dengan bobot 1000 biji paling berat $(30,91 \mathrm{~g})$ tidak berbeda nyata dibanding tanaman dengan dosis pupuk organik cair $2 \mathrm{~L} / \mathrm{ha}$ dan 4L/ha, sedangkan pengaruh utama frekuensi pemberian pupuk cair 6 kali menghasilkan tanaman dengan bobot 1000 biji paling berat $(31,04 \mathrm{~g})$ tetapi tidak berbeda nyata dengan pemberian 2 dan 4 kali.

Tabel 12. Bobot 1000 Biji

\begin{tabular}{ccccc}
\hline \multirow{2}{*}{ Dosis POC (1tr) } & \multicolumn{3}{c}{ Frekuensi Pemberian } & \multirow{2}{*}{ Rerata } \\
\cline { 2 - 4 } & 2 & 4 & 6 & \\
\hline 2 & 28,90 & 30,27 & 28,90 & $29,36 \mathrm{a}$ \\
4 & 31,23 & 30,53 & 30,07 & $30,61 \mathrm{a}$ \\
6 & 28,83 & 29,73 & 34,17 & $30,91 \mathrm{a}$ \\
\hline Rerata & $29,66 \mathrm{a}$ & $30,18 \mathrm{a}$ & $31,04 \mathrm{a}$ & $(-)$ \\
\hline
\end{tabular}

Keterangan : Angka pada baris dan kolom diikuti dengan huruf sama tidak berbeda pada taraf nyata $(\alpha) 5 \%$ menurut uji DMRT. (-) : Tidak terjadi interaksi antar faktor.

\subsection{Bobot Kering Brangkasan}

Hasil sidik ragam (Anova) menunjukkan terjadi interaksi antara perlakuan dosis pupuk organik cair dengan frekuensi pemberian pupuk organik cair pada pengamatan bobot kering brangkasan. Pengaruh utama dosis pupuk organik cair $6 \mathrm{~L} /$ ha menghasilkan tanaman dengan bobot kering berangkasan paling berat $(9,67 \mathrm{t} / \mathrm{ha})$ berbeda nyata dibanding tanaman dengan dosis pupuk organik cair 2 $\mathrm{L} / \mathrm{ha}$ dan $4 \mathrm{~L} / \mathrm{ha}$, sedangkan pengaruh utama frekuensi pemberian pupuk cair tidak berbeda nyata.

Tabel 13. Bobot Kering Brangkasan (t/ha)

\begin{tabular}{ccccc}
\hline \multirow{2}{*}{ Dosis POC (L/ha) } & \multicolumn{3}{c}{ Frekuensi Pemberian } & \multirow{2}{*}{ Rerata } \\
\cline { 2 - 4 } & 2 & 4 & 6 & $7.23 \mathrm{c}$ \\
\hline 2 & $7.05 \mathrm{~d}$ & $7.79 \mathrm{~cd}$ & $6.86 \mathrm{~d}$ & $8.43 \mathrm{~b}$ \\
6 & $8.77 \mathrm{cb}$ & $7.83 \mathrm{~cd}$ & $8.70 \mathrm{cb}$ & $9.67 \mathrm{a}$ \\
\hline Rerata & $9.18 \mathrm{~b}$ & $9.13 \mathrm{~b}$ & $10.69 \mathrm{a}$ & $(+)$ \\
\hline Keterangan : Angka pada baris dan kolom diikuti dengan huruf sama tidak berbeda pada
\end{tabular}
taraf nyata $(\alpha) 5 \%$ menurut uji DMRT. (+) : Terjadi interaksi antar faktor.

\subsection{Bobot Kering Biji Per Petak}

Hasil sidik ragam (Anova) menunjukkan tidak terjadi interaksi antara perlakuan dosis pupuk organik cair dengan frekuensi pemberian pupuk organik cair pada pengamatan berat kering biji per petak. Pengaruh utama dosis pupuk organik cair $6 \mathrm{~L} / \mathrm{ha}$ menghasilkan tanaman dengan bobot kering biji per petak paling berat $(8,90 \mathrm{t} / \mathrm{ha})$ berbeda nyata dibanding tanaman dengan dosis pupuk organik cair $2 \mathrm{~L} /$ ha dan $4 \mathrm{~L} / \mathrm{ha}$, sedangkan pengaruh utama frekuensi pemberian pupuk cair tidak berbeda nyata.

Tabel 14. Berat Kering Biji Per Petak (t/ha)

\begin{tabular}{ccccc}
\hline Dosis POC & \multicolumn{3}{c}{ Frekuensi Pemberian } & \multirow{2}{*}{ Rerata } \\
\cline { 2 - 4 }$(\mathrm{L} / \mathrm{ha})$ & 2 & 4 & 6 & \\
\hline 2 & 7.23 & 5.61 & 7.54 & $6.79 \mathrm{~b}$ \\
4 & 7.41 & 7.53 & 7.38 & $7.44 \mathrm{~b}$ \\
6 & 7.60 & 9.35 & 9.73 & $8.90 \mathrm{a}$ \\
\hline Rerata & $7.41 \mathrm{a}$ & $7.50 \mathrm{a}$ & $8.22 \mathrm{a}$ & $(-)$ \\
\hline Kennnnn
\end{tabular}

Keterangan : Angka pada baris dan kolom diikuti dengan huruf sama tidak berbeda pad taraf nyata $(\alpha) 5 \%$ menurut uji DMRT. (-) : Tidak terjadi interaksi antar faktor.

\subsection{Indeks Panen}

Hasil sidik ragam (Anova) menunjukkan tidak terjadi interaksi antara perlakuan dosis pupuk organik cair dengan frekuensi pemberian pupuk organik cair pada pengamatan indeks panen.

Tabel 15. Indeks Panen

\begin{tabular}{ccccc}
\hline Dosis POC & \multicolumn{3}{c}{ Frekuensi Pemberian } & \multirow{2}{*}{ Rerata } \\
\cline { 2 - 4 } (L/ha) & 2 & 4 & 6 & \\
\hline 2 & 50,56 & 40,90 & 51,94 & $47,80 \mathrm{a}$ \\
4 & 45,50 & 49,00 & 45,40 & $46,63 \mathrm{a}$ \\
6 & 44,85 & 50,38 & 47,62 & $47,62 \mathrm{a}$ \\
\hline Rerata & $46,97 \mathrm{a}$ & $46,76 \mathrm{a}$ & $48,32 \mathrm{a}$ & $(-)$ \\
\hline
\end{tabular}

Keterangan : Angka pada baris dan kolom diikuti dengan huruf sama tidak berbeda pada taraf nyata $(\alpha) 5 \%$ menurut uji DMRT. (-) : Tidak terjadi interaksi antar faktor.
Pengaruh utama dosis pupuk organik cair 2 L/ha menghasilkan tanaman dengan nilai indeks panen paling tinggi $(47,80 \%)$ tidak berbeda nyata dengan tanaman yang diberi dosis pupuk organik cair $4 \mathrm{~L} / \mathrm{ha}$ dan $6 \mathrm{~L} / \mathrm{ha}$, sedangkan pengaruh utama frekuensi pemberian pupuk cair tidak berbeda nyata.

\subsection{Pembahasan}

Terjadi interaksi antar faktor, penerapan perlakuan dosis $6 \mathrm{~L} / \mathrm{ha}$ dengan frekuensi 6 kali menghasilkan tanaman dengan bobot kering berangkasan paling berat (Tabel 13.), namun komponen tersebut memiliki korelasi yang sedang ( $\mathrm{r}=$ $0,49)$ dengan berat kering biji per petak.

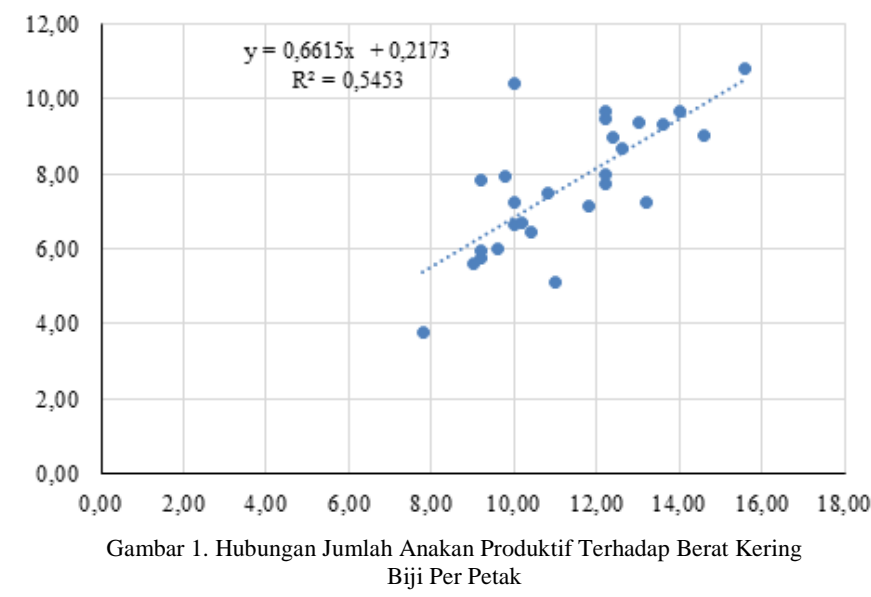

Penerapan perlakuan dosis $6 \mathrm{~L} / \mathrm{ha}$ dengan frekuensi 6 kali menghasilkan tanaman dengan jumlah anakan produktif terbanyak (Tabel 3.) walaupun tidak terjadi interaksi antar faktor.

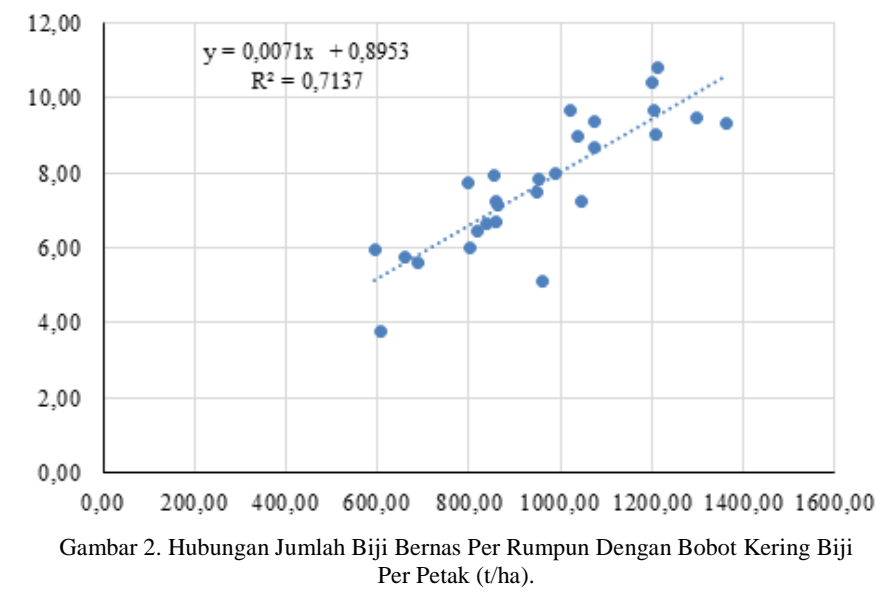

Peningkatan hasil tanaman (berat kering biji per petak) dipengaruhi oleh komponen hasil lainnya. Komponen hasil bobot 1000 biji memiliki korelasi yang rendah $(\mathrm{r}=0,32)$, tetapi komponen hasil yaitu; jumlah biji per malai $(\mathrm{r}=0,48)$, jumlah biji bernas per malai $(r=0,57)$, memiliki korelasi yang sedang dengan peningkatan bobot kering biji per petak. Korelasi yang tinggi terjadi pada jumlah anakan produktif $(r=0,74)$ (Gambar 1.), jumlah biji bernas per rumpun $(r=0,84)$ (Gambar 2.), dan bobot kering biji bernas per tanaman sampel $(r=0,99)$ dengan peningkatan bobot kering biji per petak (Gambar 3.).

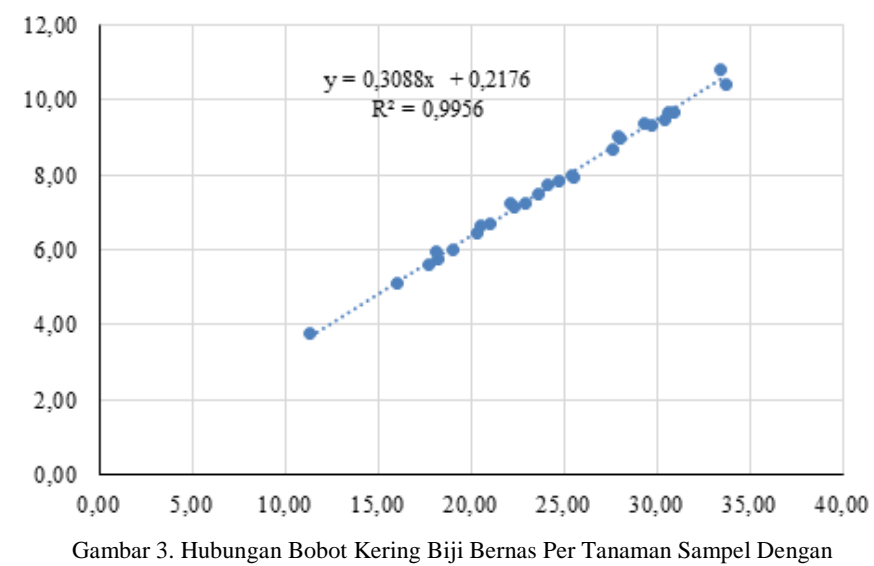
Bobot Kering Biji Per Petak. 
Pemberian pupuk organik cair lebih mudah diserap oleh tanaman baik melalui lubang stomata maupun melalui perakaran tanaman sehingga kebutuhan tanaman akan zat hara terpenuhi, yang kemudian hasil asimilasi digunakan untuk pertumbuhan dan perkembangan tanaman kemudian sisa hasil asimilasi disimpan dalam bentuk biji pada tanaman padi. Hal ini senada dengan pernyataan Surtinah (2009) bahwa, pemberian pupuk organik cair dapat dengan mudah diserap oleh tanaman sehingga penggunaan pupuk menjadi sangat efisien. Selain itu pupuk organik cair dapat memperbaiki sifat fisik, kimia, dan biologi tanah, juga membantu meningkatkan produksi tanaman, kualitas produk tanaman (Parman, 2007). Selanjutnya laporan Hadi (2005) menyatakan bahwa unsur Fosfor berperan dalam menyimpan dan memindahkan energi untuk sintesis karbohidrat,protein, dan proses fotosintesis. Senyawa-senyawa hasil fotosintesis disimpan dalam bentuk senyawa organik yang kemudian dibebaskan dalam bentuk ATP untuk pertumbuhan tanaman.

\section{Simpulan}

Terjadi interaksi antara perlakuan dosis dan frekuensi penyemprotan pupuk organik cair terhadap tanaman padi sawah pada beberapa parameter pengamatan yaitu Jumlah biji per malai, Jumlah biji bernas per malai, Berat kering biji hampa per tanaman sampel, Berat kering brangkasan. Dosis pupuk organik cair TOP terbaik adalah $6 \mathrm{~L} / \mathrm{ha}$ dengan hasil berat kering biji sebesar 8,90 t/ha dengan frekuensi penyemprotan tidak berbeda nyata.

\section{Pustaka}

Astawan, M. 2004. Kandungan Serat dan Gizi pada Roti Ungguli Mie dan Nasi. Kompas Cyber Media, Jumat, 18 Juni 2004.

Badan Pusat Statstik Kab Belu 2014. Sensus Pertaniaan

Hadi. 2005. Abu Sekam Padi Pupuk Organik Sumber Kalium Alternatif pada Padi Sawah. GEMA, Th. XVIII/33/2005. Hal $38-45$

Gomez, K. A dan A. A. Gomez. 1995. Prosedur Statistika untuk Penelitian Pertanian. Diterjemahkan oleh E. Syamsudin dan J. S. Baharsyah. UI Press. Jakarta.

Parman, 2007. Pengaruh Pemberian Pupuk Organik Cair Terhadap Pertumbuhan dan Produksi Kentang (Solanum Tuberosum L.).Buletin Anatomi dan fisiologi Vol. XV. No. 2.6-38

Suriadikarta, Didi Ardi, Simanungkalit, R.D.M. (2006). Pupuk Organik dan Pupuk Hayati. Jawa Barat: Balai Besar Penelitian dan Pengembangan Sumber daya Lahan Pertanian. Hal 2.

Surtinah. 2009. Pemberian pupuk Organik Super Natural Nutrition (SNN) Pada Tanama Selada (Lactuca sativa, L ) di tanah utlisol . Jurnal Ilmiah Pertanian Vol. 6 No. 1 Agustus 2009

Purnamaningsih . 2006. Induksi kalus dan optimasi regenerasi empat varietas padi melalui kultur in vitro. Jurnal AgroBiogen 2(2):74-80.

Wawo, 2013. Pertumbuhan dan hasil padi sawah (Oryza sativa, L .) akibat pengunaan beberapa tipe jarak tanam Metode jajar legowo dan dosis bokashi cair. 